
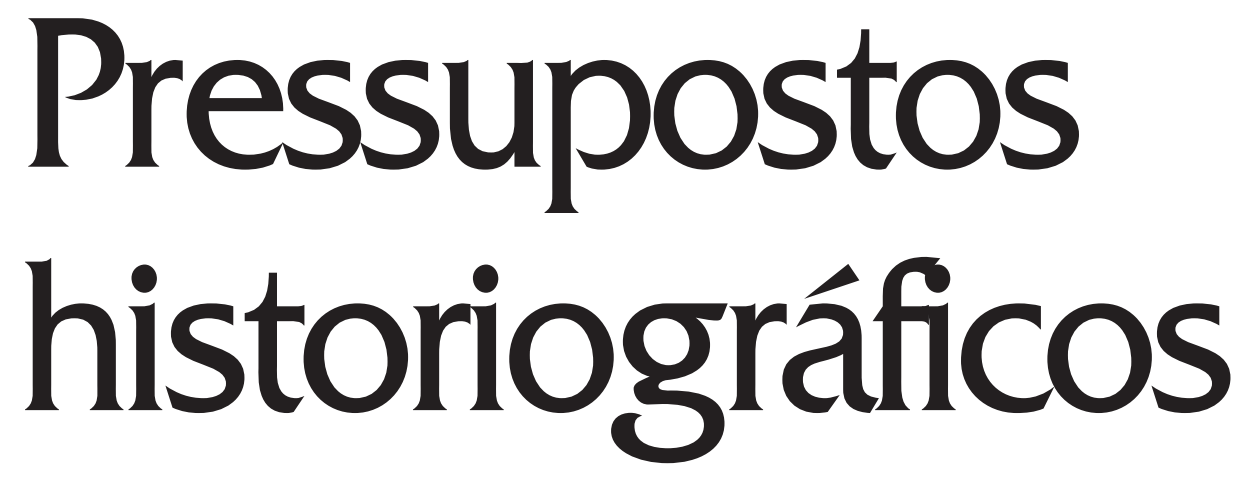

\title{
para uma leitura de
}
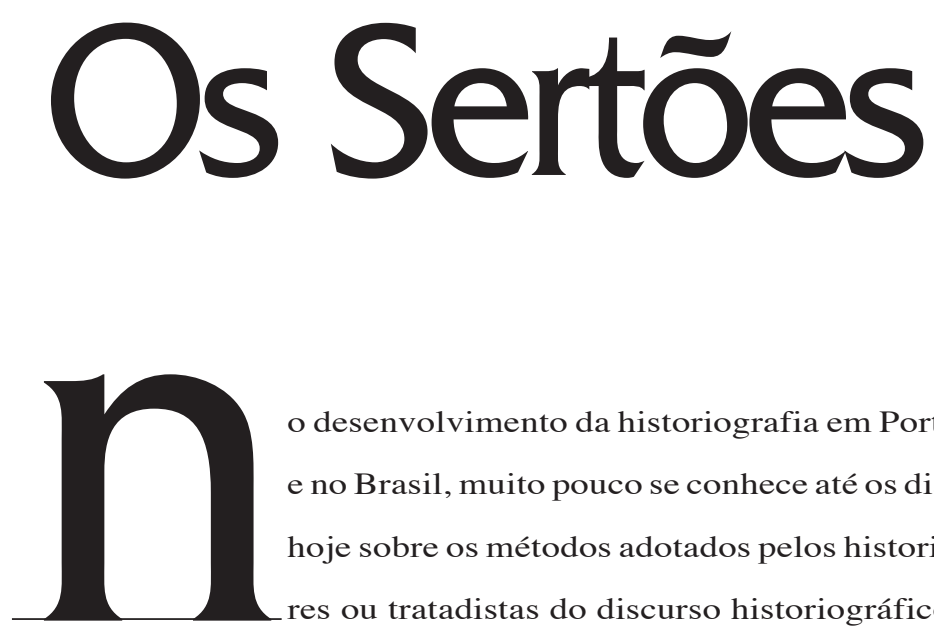

o desenvolvimento da historiografia em Portugal

e no Brasil, muito pouco se conhece até os dias de hoje sobre os métodos adotados pelos historiadores ou tratadistas do discurso historiográfico, ao contrário do que ocorreu em outras línguas. Em italiano, a coleção de estudos dessa natureza é rica. No lado espanhol, o cabedal Na página seguinte, ilustração de capa da edição holandesa de Os Sertões

\section{LEOPOLDO $M$.}

BERNUCCI é professor na Universidade do Texas, em Austin (EUA), e organizador da edição de Os Sertões pela Ateliê Editorial, Imprensa Oficial do Estado e Arquivo do Estado. acumulado, principalmente a partir do século XVII, é significativo. De qualquer maneira, ambos os casos deixam ver o notável interesse havido, por um lado, quanto à forma historiográfica mais justa ao conceito de verdade e, por outro, quanto ao modo de narrar mais belo e agradável ao intelecto.

Nem a obra de Ambrósio Fernandes Brandão, Diálogos das Grandezas do Brasil (1618), nem a de frei Vicente do Salvador, História do Brasil (1627), e nem ainda a do padre Simão de Vasconcelos, Crônica da Companhia de Jesus (1663), a despeito da 


\section{os sertões ấs}

qualidade e utilidade das matérias narradas, preocuparam-se em traçar sistematicamente as linhas mestras do fazer historiográfico para dar conta do novo território do Império Lusitano. Esta penúria conceitual encerra uma conclusão lastimável no desenrolar das idéias de como escrever a história entre nós e faz ressaltar o modo rudimentar da crônica, fortemente calcado na relação primordial dos fatos.

Não se compreende por que razão, talvez por preconceito de escola, ao passar em revista nossos chamados historiadores coloniais, "cronistas" em todo o caso, a maioria dos historiógrafos do século XIX prescinde de qualquer avaliação sobre o método historiográfico de Sebastião da Rocha Pitta (1). Se para esses críticos a História da América Portuguesa (1730) peca por ser demasiado pomposa e afetada na sua linguagem barroca carregada de ornamentação retórica, adulatória no seu tom e pouco fidedigna na comunicação dos aspectos verídicos dos fatos, ela deveria no entanto redimir-se pelo reconhecimento de uma arte que o autor estaria tentando produzir (2). Infelizmente, não foi assim a sua fortuna crítica; pois, para estarem convencidos dessa arte, bastaria terem visto com que autoconsciência artística Rocha Pitta abre o seu livro, equiparando o trabalho do historiador ao do pintor, ao declarar que aquele "não teme sair dos preceitos da história

quando altera a pureza das suas leis com as idéias da pintura, que requer mais valentes fantasias, tendo por exemplar portentos, em que a mais elevada frase poética é verdade ainda mal encarecida" (p. xviii).

$\mathrm{Na}$ série de licenças que precedem a História da América Portuguesa, dom Antônio Caetano de Sousa, clérigo regular, qualificador do Santo Ofício, consultor da Bula da Santa Cruzada e membro da Aca-
Já na fase de conclusão do presente ensaio, fui informado por fonte amiga sobre um sé rio estudo dedicado à maté ria, o qual não tive oportunida de de ler. Trata-se da disserto ção de mestrado de Eduardo Sinkevisque, dirigida pelo prot. oão Adolfo Hansen: Retórica e Política: a Prosa Histórica do Séculos XVII e XVIII, Area de Literatura Brasileira, DLCVFFLCH-USP, junho de 2000

"Não será até o século XVI" como recorda Walter Mignolo "que o vocábulo 'Ars' aparece nos tratados de historiografia" VerMignolo, "ElMetatexto Historiográfico y la Historiografía Indiana", in Modern Languague Notes, 96, 1981 


\section{HISTOR/A}

\section{AMFRICA POR'IIJGIJE'ZA}

DESDE O ANNO DE MIL E QUINHENTOS DO SEU DESCOBRIMENTO ATÉ O DE MIL E SETECENTOS E VINTE E QUATRO

O포토도A

A MAGESTADE AUGUSTA DEL-REI D. JOÃO V, NOSSO SENHOK COMPOSTA POR

\section{SEBASTIÃO DA ROCHA PITTA}

Fidalgo da Casa de Sua Magestade, Cavalleiro professo da Ordem de Christo, Coronel do Regimento da Infanteria da Ordenança da Cidade da Bahia e dos Privilegiados d'ella

e Academico supranumerario da Academia Real da Historia Portugueza.

\section{SEGUNDA EDIÇÃO}

\section{Revista e annotada por F. G. Goes}

Official da Bibliotheca Nacional de Lisboa.

ORNADA COM SEIS BELLAS GRAVURAS E UM MAPPA
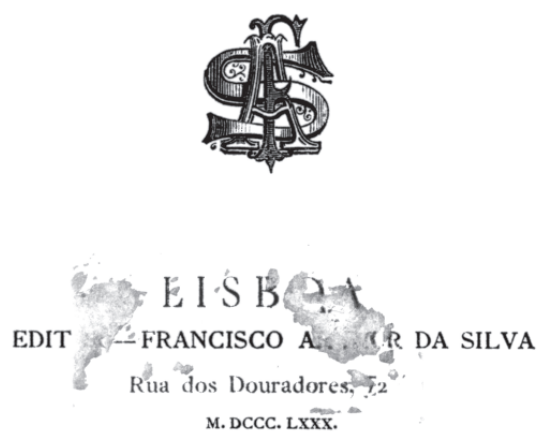

Falsa segunda edição de

Historia da

America

Portugueza demia Real da História, nota uma particularidade que Rocha Pitta teria utilizado como conseqüência de sua evidente preocupação com o estilo e com a linguagem: "se empregou em escrever esta história, que, sendo principalmente política, tem muito da natural, pelo que se faz mais agradável". Em defesa do autor, o religioso ainda nota “que excedendo as hipérboles, não ofendem a verdade, lei essencial para a história do que os outros mais rigorosos preceitos com que ela se deve compor. Este autor o faz em estilo tão elegante, que tem muito de poético" (pp. xx-xxi).
Outro clérigo, frei Boaventura de São Gião, elogia o livro porque "pontualmente cumpre os preceitos da narração e [d]as leis da história; porque determina ações, ajusta anos, observa tempos, distingue lugares, demarca terras, individua sucessos, reduzindo a abreviados períodos o que pudera ser matéria de copiosos tratados" (p. xxiii). Não escapa tampouco ao censor a observação sobre a dispositio dos assuntos: "Estou certo se há de ler a presente história com gosto e sem fastio, pela boa ordem e admirável disposição com que está composta, novidades que refere, particularidades que relata, elegância com que se adorna; porque o estilo é grave, especioso e agradável; natural, sem artifício e culto, sem afetação, e tão singular que não tem regra ociosa, oração supérflua” (p. xxiv)(3).

Se no século XIX internamente não tivemos um espírito crítico e sobretudo lúcido para mapear teoricamente os caminhos da historiografia no Brasil, não nos faltou quem nos mostrasse na prática as mudanças que se operavam no campo da escritura da história. O papel que desempenha o visconde de Porto Seguro, Francisco Adolfo de Varnhagen, no desenvolvimento das nossas atividades historiográficas é fundamental no tocante à seriedade da pesquisa e ao levantamento de dados nos arquivos. Outro tanto deve ser dito com respeito ao seu esmerado trabalho de tradução, recopilação e divulgação de documentos encontrados nos acervos de documentos históricos portugueses. Além de prestar contribuições documentais valiosas para os períodos compendiados, sua História Geral do Brasil serve, hoje, como apreciável fonte para o estudo da evolução dos estilos historiográficos no Brasil, particularmente como exemplo do ideário historiográfico do Instituto Histórico e Geográfico, muito empenhado em atender aos interesses específicos das elites letradas do Segundo Reinado, que, como se sabe, procuraram, sob direta tutela de d. Pedro II, instituir um passado colonial que justificasse a direção política do seu Império.

Em igual linha de reconhecimento do valor atribuído à História Geral do Brasil, 
mas a contrapelo da ideologia e do discurso monarquistas do visconde de Porto Seguro, estão os Capítulos de História do Brasil de Capistrano de Abreu. Contudo, a presença excepcional de Capistrano no panorama historiográfico do século XIX não deve se restringir somente a esta obra. Foi ele que, sendo mais crítico que encomiástico, aludiu a Carl Friedrich P. von Martius (4) e revelou também um método que passaria, sob muitos aspectos, a constituir o seu "próprio" modo de conceber o passado, mas dessa vez através de uma história literária que, curiosamente, também pode oferecer-se como modelo ideal para a escritura de uma história do Brasil (5). Não deixemos, porém, que a forte impressão causada por essa crítica dirigida ao modelo de Martius nos faça pensar num grande distanciamento entre este e o modelo capistraniano, porque, na verdade, eles são semelhantes. Ambos estão caracterizados por um enfático recorte determinista apoiado nos três elementos já conhecidos: raça, meio e momento histórico. Martius argumenta de modo livre e pessoal; Capistrano, baseando-se em fontes e em autoridades (Stuart Glennie, Thomas Buckle, Hypolite Taine, Auguste Comte, Herbert Spencer, Claude Bernard), disserta de maneira acadêmica.

No plano da ideologia, a confluência de conceitos entre ambos os autores é indiscutível, mas já num outro nível, o da organização das matérias, um exame mais detalhado do ensaio de Martius revela sua capacidade para pormenorizar os componentes do esquema historiográfico de que o discurso de Capistrano carece, já que este segue, na somatória do seu estilo, o princípio da síntese, propriedade que a crítica, coincidentemente, reconhece nos Capítulos. No esquema historiográfico proposto por Martius poderia muito bem estar baseado - de modo seletivo, é certo - o plano que Euclides da Cunha delineou para $O s$ Sertões.

Várias razões apontam para o desenho metodológico com que se concebeu o livro sobre a Campanha de Canudos: a formação do tipo brasileiro, a partir do caldeamento das três raças; a investigação sobre as lín- guas indígenas, como curiosidade etnográfica que Euclides analisa com o auxílio de Teodoro Sampaio; o estudo sobre a mitologia e crenças que Martius resume da seguinte maneira: "Pesquisas tais, necessariamente, nos levarão para estes fenômenos pertencentes à esfera de superstições, de virtudes curativas de taumaturgos índios, feiticeiros e curandeiros" (6); as indagações sobre a descoberta de sítios arqueológicos; o papel fundamental do português na colonização do Brasil; o conhecimento da história civil e legislativa desde os primórdios da colônia; a presença marcante dos jesuítas; as relações sociais entre colonos e servidores (escravos ou criados); o progresso da poesia e da retórica; a vida científica, moral e social do Brasil; a vida militar; as incursões das entradas pelos sertões; histórias e legendas sobre as riquezas subterrâneas do país e a poesia popular.

Definitivamente, o modelo sugerido por Martius preza-se por ser totalizante e pela forma como, sendo inclusivo, o historiador deverá abarcar os pontos principais do seu método organizacional. E será já investido do papel de filósofo da história que Martius julgará no seu ensaio algumas de nossas "histórias" do Brasil, ditando as coordenadas que, segundo ele, deveriam pautar o melhor modelo:

“Elas [as histórias do Brasil] abundam em fatos importantes, esclarecem até com minuciosidade muitos acontecimentos; contudo, não satisfazem ainda as exigências da verdadeira historiografia, porque se ressentem demais de certo espírito de crônicas. Um grande número de fatos e circunstâncias insignificantes, que com monotonia se repetem, e a relação minuciosa até o excesso de acontecimentos que se desvaneceram sem deixarem vestígios históricos; tudo isso, recebido em uma obra histórica, há de prejudicar o interesse da narração e confundir o juízo claro do leitor sobre o essencial da relação. O que avultará repetir-se o que cada governador fez ou deixou de fazer na sua província, ou relacionar fatos de nenhuma importância histórica, que se referem à administração de cida- pp. 358-402. Consultar ainda: Menéndez y Pelayo, "De la Historia Considerada como Obra Artística" (Discurso de ingreso a la Real Academia de la Historia), 1883, in Estudios de Crítica Literaria vol. Madrid 1893 ,pp. 81-135; e Benedetto Croce, "La Storia Ridorra Sotto el Concetto Generale dell'Arte", in Primi Saggi, Bari, 1919

3 Sebastião da Rocha Pitta, História da América Portuguesa Lisboa, Francisco Artur da Si va, 1880

4 Martius sugere o seu modelo historiográfico em dissertação ferecida ao Instituto Histórico e Geográfico Brasileiro intitulada "Como se Deve Es crever a História do Brasi" (Munique, 1843). Ver Revista do Instituto Histórico e Geográ fico Brasileiro, VI, 1844, pp. 389-4 11 .

5 Ver Capistrano de Abreu, "A Literatura Brasileira Contemporânea" in Revista da Acade mia Brasileira de Letras, no 16 1920, pp. 241-83. Este artigo foi publicado inicialmente em O Globo de 18 de de zembro de 1875. Consultar também o irrevente e dispara tado ensaio de Sívio Romero Carlos Frederico F. de Martius e suas Idéias Acerca da Histó ria do Brasil" in Revista da Academia Brasileira no 8 1912, pp. 231-72.

6 Idem, ibidem, p. 395. 
des, municípios ou bispados, \& etc.; ou uma escrupulosa acumulação de citações e autos que nada provam, e cuja autenticidade histórica é por vezes duvidosa? - Tudo isso deverá, segundo a minha opinião, ficar excluído" (p. 407).

Embora mereça ser repisado, não é reparo tão singular dos que contemplam o percurso dos historiadores antigos observar que Tácito intitule Histórias os relatos que ocorrem em seu próprio tempo; e Anais, a narração dos fatos que ele não pôde conhecer como testemunha de vista (desde a tomada do poder por Tibério até a morte de Nero) (7). Dentro de semelhantes considerações metodológicas, o leitor assíduo de Heródoto notará também que as descrições da paisagem de territórios estrangeiros se combinam perfeitamente com as narrações de eventos históricos. E, por fim, quem frequienta Tucídides perceberá que o seu foco se dirige aos avatares políticos de um povo, limitando-se a descrever ambientes naturais, contos insólitos, estórias sobre indivíduos famosos, mitos e cultos ou informando sobre monumentos conhecidos por sua beleza ou grandeza. As fontes nele, quando não reveladas ao leitor, são difíceis de serem reconstruídas, mas o critério para a ordenação dos depoimentos orais e de sua

À direita, Capistrano de Abreu

7 Mignolo, op. cit., p. 367

8 Cf. Arnaldo Momigliano Studies in Historiography, Nova Yorke Evanston, Harper \& Row, 1966, p. 214.

9 A ciłação provém do parágrato 22 da História da Guerra do Peloponeso. Em Os Sertões aparece à pagina $784 \mathrm{da}$ nossa edição. coerência interna é rigoroso (8). Apesar das diferenças, há, sem dúvida, um forte laço que une o modelo de Euclides da Cunha ao de Tucídides, a começar por aquela declaração de princípios que aparece nas "Notas à $2^{\mathrm{a}}$ edição":

" [S] em dar crédito às primeiras testemunhas que encontrei, nem às minhas próprias impressões, mas narrando apenas os acontecimentos de que fui espectador ou sobre os quais tive informações seguras" (9).

Ao leitor curioso da tradição das histórias naturais que remontam a Plínio, não poderá passar despercebido tampouco o fato de que Martius, sendo tão ilustre naturalista, proponha uma história muito mais complexa do que apenas um mero tratado cien- tífico. Vale dizer, a proposta que oferece o cientista alemão se aproxima muito mais do modelo de Heródoto que do de Plínio. Discorrendo, de novo, sobre a melhor maneira de escrever uma história do Brasil, aconselha no fecho do seu ensaio, citando o historiador grego, "que não excitará nenhum interesse vivo, nem lhes poderá desenvolver as relações mais íntimas do país, sem serem precedidos os fatos históricos por descrição das particularidades locais da natureza" (p. 408).

Ora, essa preocupação com os componentes que formam a matéria narrativa torna-se, para um escritor como Euclides, motivo também de conscientização discursiva; isto é, de exercitar com todo zelo necessário o equilíbrio dos assuntos ali tratados. Acicatado por essa questão, o autor construiu uma história que combina diversidade temática com pluralidade discursiva, seguindo o esquema historiográfico prescrito por Martius. Tudo leva a crer, então, que no conceito de uma escritura da História reservada para Os Sertões tenham entrado as idéias do escritor bávaro. A julgar por um documento ainda inédito de Teodoro Sampaio, em cujas folhas Euclides intercalou páginas de ensaios que

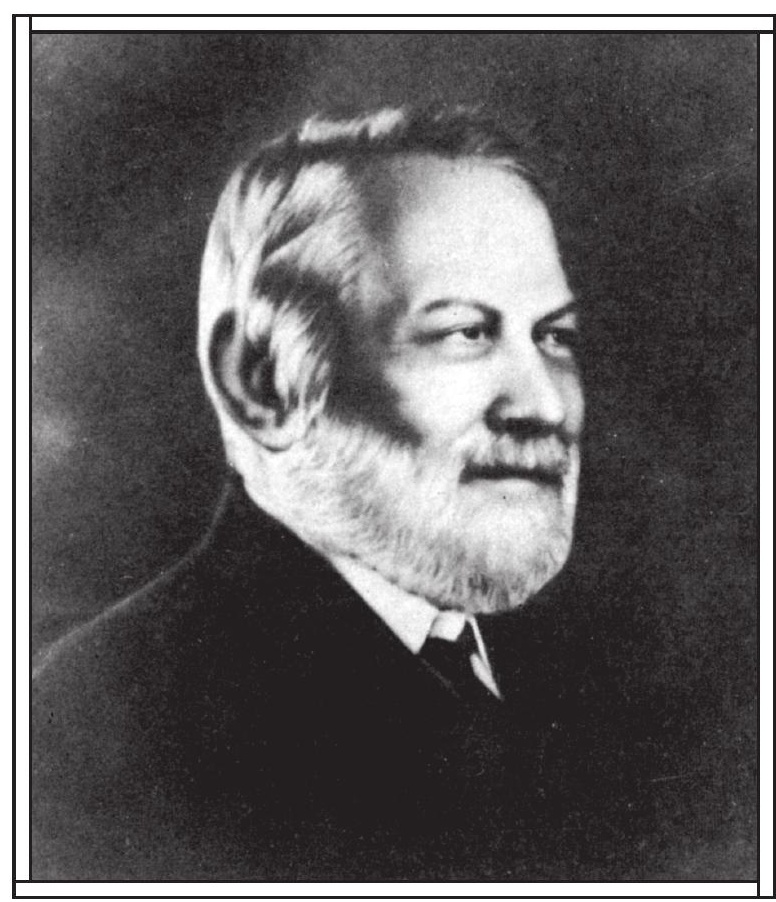


viriam depois compor Contrastes e Confrontos, não seria exagero dizer que os dois autores executariam suas obras sob as mesmas instruções de Martius. Ali, Teodoro se refere ao naturalista alemão justamente a propósito do ensaio publicado pela Revista do Instituto Histórico e ao qual estamos aludindo(10). Euclides conhecia muito bem esse manuscrito de Teodoro, um esboço de uma suposta História do Brasil, e dada a sua familiaridade com a Revista do Instituto nos permitimos especular que ele também compartilhara a receita do autor de Flora Brasiliensis.

Qualquer que seja a hipótese de uma adesão historiográfica ao modelo de Martius, convém lembrar que ele era o mais complexo dos que até então haviam sido empregados, se o colocarmos frente àquelas pálidas tentativas de dar forma e corpo narrativos aos nossos sucessos históricos. Parte do problema era que os chamados relatos historiográficos sobre o Brasil se atrelavam aos formatos da crônica e da relação, enquanto formas narrativas um pouco melhoradas das que também faziam uso os anais desde a Antigüidade, entendidos estes como simples registros cronológicos de acontecimentos e não como narrações propriamente de fatos. Martius estava convencido de que não bastavam os tópicos históricos e que "[c]omo qualquer história que este nome merece, deve parecer-se com um Epos” (p. 410). Daí vir o seu conselho para se obter o melhor discurso empregado, o qual deveria "satisfazer não menos ao coração do que à inteligência [e] por isso não dev[eria] ser escrita em uma linguagem [...] empolada, nem sobrecarregada de erudição ou de uma multidão de citações estéreis. Evitará não menos ter o caráter de uma crônica, do que de investigações históricas, secas e puramente eruditas"; e acrescentará: “[...] deverá ser escrita em um estilo popular, posto que nobre" (p.410).

Nobre quer dizer grave ou sublime, na terminologia empregada pelas poéticas e é assim, por exemplo, que procede Euclides em Os Sertões, quando, desviando-se do preceito da transcrição literal da fala dos jagunços (canaias), tal como fora anotada

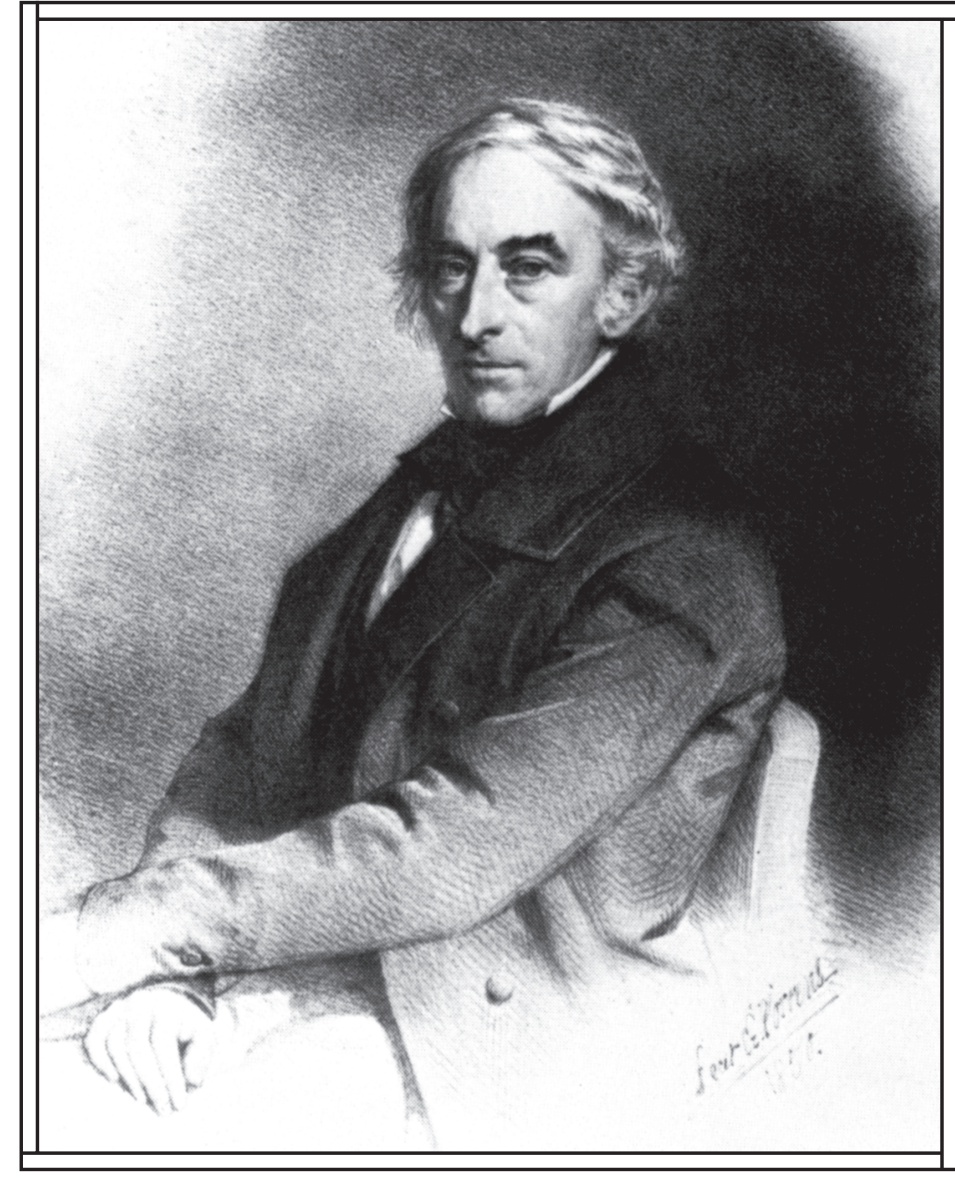

na Caderneta de Campo e que teria contribuído para um maior grau do efeito do real discursivo, o nosso autor eleva o estilo com o uso da forma dicionarizada, canalhas (11), violando a regra do decoro. Basta somente esta constatação para explicar, ao nível discursivo, a escolha deliberada que faz o autor de um registro de fala que fosse o mais adequado ao tom e assunto gerais de um livro, no qual predomina o espírito da epopéia e da tragédia.

Arnaldo Momigliano afirma que "os historiadores do século XIX estavam menos preocupados com a coleta de material que com a narração de uma estória e a compreensão adequada desta estória" (12). Assim parece ser também o caso de Euclides, que não prescindiu da pesquisa nos arquivos e da coleta de testemunhos enquanto esteve na Bahia durante o período final da guerra. É sabido também que ele pôde escrever sobre aspectos da natureza e dos homens do sertão sem haver estado em
Carl Friedrich

Philip von

Martius,

Biblioteca

Cássio Cotrin 
contato direto com eles até os últimos dias da Campanha. A exemplo de Tucídides, será o consórcio entre arte, exatidão e o tom sincero do narrador que modelará $O s$ Sertões como história ao gosto do Romantismo. Patriótico, artístico, infatigável perseguidor de uma expressão justa, embora subjetiva, da verdade, Euclides, como Tucídides, na bela descrição que faz deste Momigliano, transmite-nos a sua paixão política de modo dramático e vibrante (13).

Firmada nesses princípios básicos de organização discursiva, a historiografia do século XIX ponderou também, com muito mais rigor e recato, os riscos a que ela se submetia, se o historiador não estivesse atento à noção de verdade; porque toda narração considerada histórica se modelava até então a partir de dois princípios fundamentais: a coleta dos dados históricos e a busca de um discurso conveniente à noção de verdade. Mas é forçoso reconhecer que, independentemente de quaisquer épocas, imaginar uma história que forjasse mentiras ou, irresponsavelmente, cometesse erros grosseiros de interpretação dos fatos comprometendo de forma aviltante o conceito de verdade - seria o mesmo que vislumbrar o fim da própria atividade historiográfica (14).

Assim, a historiografia requer do historiador uma disposição mental ética que não existe no campo da ficção. E a razão é relativamente simples, porque o romance, por exemplo, lida com o conceito de verossimilhança e não de vericidade; e se por acaso os elementos de uma representação ficcional dos fatos coincidirem com os de uma narração de sucessos históricos, não se deverá pensar que o romancista quis aderir a um preceito verdadeiro da mesma maneira como o faz o historiador. Aliás, na eventualidade de que a sua preocupação seja realmente com a realidade, esta é admissível somente quando considerada como categoria das coisas possíveis do mundo da ficção. Portanto, mesmo se a comunicação do verdadeiro ou do verídico for prioridade do artista, esta só será concebida como representação e jamais como narração veraz de acontecimentos.
Já se discutia entre os antigos filósofos da história a questão da verdade de re (dos fatos) e de dicto (da narração) (15). Cícero abordou o problema da verdade moral que concerne à narração do fatos, enquanto Plínio se interessou pelo conceito da verdade natural que afeta as próprias coisas. São duas maneiras de lidar com um único conceito resultante de dois métodos: um empírico, porque necessita a verificação dos dados na arqueologia que a atividade historiográfica pressupõe; e outro de maior densidade moral, porque implica uma articulação da linguagem que não somente possa convencer, do ponto de vista retórico, mas que também logre comunicar com grande eficiência, e de forma ética, a verdade dos fatos tal como esta é concebida através da pena de cada historiador.

Na ficção, os conceitos são outros. Se não é possível determinar com consistência a aplicação das regras de verossimilhança aos vários discursos ficcionais existentes, é possível entender com precisão o funcionamento das diversas realidades verossímeis. As regras da verossimilhança num conto de fadas são muito diferentes das de um conto realista, mas em ambos os casos a finalidade é uma só, manter a coerência interna do texto. No mundo de Cinderela as diversas transformações presenciadas pelo leitor (e.g., da abóbora em carruagem, dos ratos em cavalos e cocheiros, etc.) parecem ser absolutamente "naturais"; pois são esperadas e aceitáveis pela lógica do texto. Aquele que não tolerar tais acontecimentos e personagens será mau leitor, não compreendendo o protocolo que este gênero literário (conto de fadas) estabelece. Mas retornemos ao assunto principal.

Se no plano estilístico de Os Sertões houve uma seleção cuidadosa dos determinantes linguiísticos empregados pelo autor, igualmente, no plano da organização das matérias narradas, a escolha dos assuntos não poderia receber menor atenção de sua parte. Poderíamos inclusive perguntar por que ele achava que, como está dito no prefácio, sem ser publicada no ano da guerra ou próximo a 1897, a narração simples e exclusivamente dos acontecimentos da 
Campanha de Canudos pudesse perder sua atualidade. É impossível aceitar essa hipótese hoje em dia, já que o trecho mais longo do livro, "A Luta", não envelheceu e muito menos o seu conjunto. Ambos, como se vê, continuam a conquistar leitores depois de um século de existência. Porém, a observação do autor deveria fazer-nos parar para pensar no excesso de preocupação que ele tinha com respeito à qualidade efêmera e problemática das fontes jornalísticas que, irremediavelmente, estavam sendo utilizadas na escritura daquela obra de imerecido título inicial, A Nossa Vendéia (16). Isso mostra até que ponto Euclides não pôde deixar de recorrer aos jornais para escrever "A Luta", enquanto, para as demais seções, o recurso aos livros e ensaios científicos o
16 Título original do livro tal como havia sido anunciado nos jornais durante o ano da Campanha de Canudos.

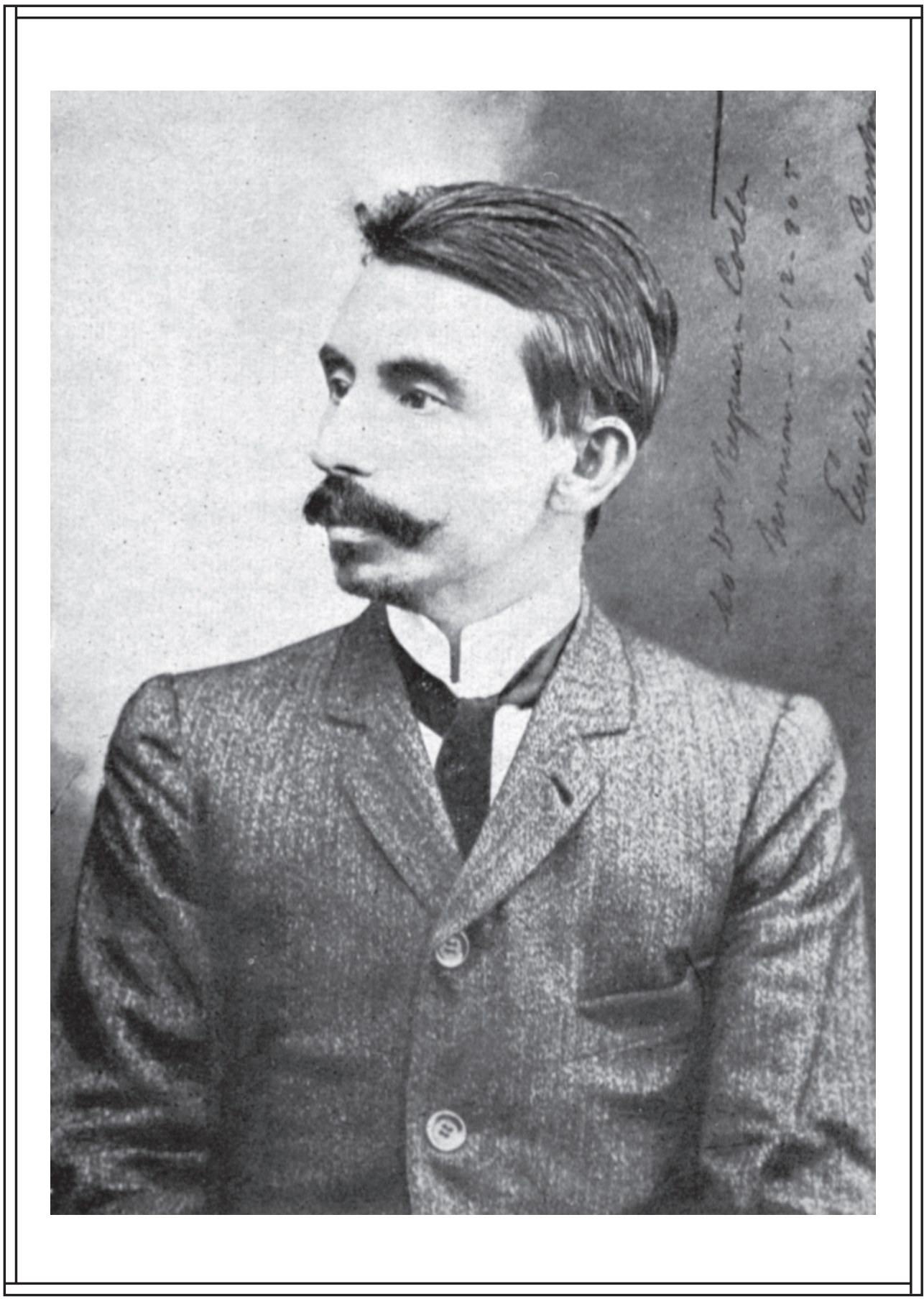

Euclides da Cunha, 1905 
fazia mover-se com maior segurança e autoridade.

Poderíamos, ainda, indagar se Euclides já não intuía poeticamente aquele distanciamento temporal tão típico da épica e necessário para os fatos que porventura parecessem impossíveis, porque não passariam diante dos olhos do espectador como costuma suceder na tragédia. Já na epopéia, tornam-se assim, com a ajuda dessa distância no tempo, aceitáveis ou ocorrem quase despercebidos. É o caso, para elucidar um par de exemplos, da passagem em que, depois do saque do arraial pelas forças do exército, o narrador descreve as armas encontradas dentro das taperas:

"Entre estas últimas, gradações completas, desde a de cano fino, carregada com escumilha, até à 'legítima de Braga', cevada com chumbo grosso, ao trabuco brutal ao modo de uma colubrina portátil, capaz de arremessar calhaus e pontas de chifres, à lazarina ligeira, ou ao bacamarte de boca de sino" (17).

A hipérbole das últimas linhas do texto euclidiano se arrisca ao terreno do improvável. Quem ousaria imaginar tremendo arsenal de caserna, com armas de gradações completas, abrigadas num mirrado rancho de pau-a-pique? O extravasamento, no entanto, leva à frente a idéia do conjunto, ignorando o desajuste desta vinheta bélica no painel mais amplo da descrição do lar.

Igualmente, alguns dos contraditórios ou paralogísticos juízos do narrador revelam falsas ilações que não se sustentam sob a verificação empírica de uma leitura mais atenta, comoé o caso das igrejas construídas por Antônio Conselheiro que podem ser elegantes e belíssimas (pp. 279, 282) num momento pesadas, rudes imperfeitas num outro (pp. 306-7). Razões de ser da arte, enfim, que também indicam a presença improvável, já noutra ordem das coisas, da abundância de iguarias e de água, durante os dias de completa escassez da guerra. Era um preceito caro a Euclides que explica, em parte, o seu realismo "engenhado por uma idealização afogueadíssima” (18):
“Quase sempre, depois de expugnar a casa, o soldado faminto não se forrava à ânsia de almoçar, afinal, em Canudos. Esquadrinhava os jiraus suspensos. Ali estavam carnes secas no Sol; cuias cheias de paçoca, a farinha de guerra do sertanejo; aiós repletos de ouricuris saborosos. A um canto os bogós transudantes, túmidos de água cristalina e fresca. Não havia resistir” (p. 471).

Vejamos agora a complexa relação de Euclides com a imprensa de seu tempo. $\mathrm{Na}$ verdade, qual era o problema com os jornais? Uma das respostas seria a sua desconfiança das matérias narradas. Estando essas na maioria das vezes marcadas por imprecisões e incoerências, quandonão por versões mirabolantes e sensacionalistas, as informações extraídas da imprensa levantavam suspeitas (19). Mas como evitá-las? Se eram praticamente a única fonte, e digase de passagem copiosa, à qual Euclides podia ter acesso durante aqueles meses da Campanha. É bem verdade que mesmo outros textos publicados em forma de livro mais tarde, como os dados biográficos sobre Antônio Conselheiro de João Brígido ou Os Jagunços de Arinos, foram divulgados originalmente em jornais, como também ainda no período da guerra foi ao prelo o imprescindível Relatório de frei João Evangelista que poderia ter chegado a Euclides através dos diários (20). Em suma, a imprensa era um mal necessário. E se quisermos ainda uma amostra mais contundente da dívida de Euclides, com respeito às informações colhidas na imprensa, teremos que nos referir aos últimos momentos da vida do coronel Moreira César. Como já mostramos algures, para narrar as últimas palavras e gestos do malfadado militar em Os Sertões, Euclides teve que reelaborar um trecho do colaborador anônimo do Jornal do Brasil, responsável pela coluna "Interesses Militares"(21). Reprisemos esta cena:

\section{Jornal do Brasil (25/4/1897)}

"Como intervir de modo a fazê-lo prosseguir com o mesmo élan que iniciou? O coronel pagou caro o muito que confiou nas 
suas forças e o pouco valor que deu às do contrário. 'Vou reanimar aquela gente', foram as suas palavras e, esporeando o cavalo, galopou para o flanco direito, onde soube escassearem munições à polícia.Voltando as rédeas, regressa para providenciar, quando, visado com segura pontaria, recebe em cheio um tiro no abdômen".

\section{Os Sertões (p. 475)}

"O movimento complementar quebrava-se assim aos primeiros passos. O chefe expedicionário deixou então o lugar em que permanecera, a meia encosta dos Pelados, entre a artilharia e o plaino das quixabeiras: - Eu vou dar brio àquela gente...E descia. A meio caminho, porém, refreou o cavalo. Inclinou-se, abandonando as rédeas, sobre o alção dianteiro do selim. Fora atingido no ventre por uma bala".

Por ser mais narrativa a terceira parte do livro ("A Luta"), pareceria natural que certos relatos ficcionais propiciassem a Euclides o ensejo de poder reconstruir alguns dos melhores quadros da guerra (e.g., Os Jagunços de Afonso Arinos) e de ajudálo na elaboração de um elenco extraordinário de personagens (e.g., Quatre-veingt treize de Victor Hugo). Todavia, contrariando esta lógica, mesmo estando em terreno etnográfico em que predominam normalmente as descrições e análises, Euclides usou matrizes ficcionais que vieram muito a calhar. Pensemos nas passagens da segunda parte, “O Homem", e vejamos como Alencar (e.g., O Sertanejo e O Gaúcho) pôde auxiliá-lo. Consideremos também o trecho biográfico de Antônio Conselheiro e notaremos a influência de outro texto ficcional menos conhecido, a peça dramática Antônio Maciel. O Conselheiro de Júlio César Leal (22).

A incorporação de materiais extraídos de fontes ficcionais combinados com os das fontes históricas, científicas e jornalísticas faz de Os Sertões a primeira grande obra verdadeiramente canibalesca da nossa literatura; um belo antecedente dos textos modernistas, principalmente se levarmos em conta o elevado grau de devoração ou assimilação de materiais alheios e a atitude pouco cerimoniosa ao deglutir tudo o que encontra pela frente: artigos em periódicos, livros de história e de ficção, estudos sobre folclore, antropologia e ciências naturais, manuscritos de colegas e dicionários. No plano argumentativo, para dar a Os Sertões vida historiográfica, o autor trabalha o argumento da história de Canudos de modo que seja percebida como tragédia. Arma o seu argumento em torno da hecatombe final e imprime-lhe um crescendo que anima essa destruição. A força explicativa, ele irá buscá-la nas ciências e nas correntes filosóficas de sua época, fortemente caracterizadas pelas análises de causa e efeito dos fatos, o que, inevitavelmente, confere ao livro um esquema mecanicista, porquanto também este cria um sentido metafórico para a narração: as análises históricas e sociológicas são feitas com base em repetições ou casos já presenciados ao longo das lutas político-religiosas do mundo ocidental (23).

Vale a pena recordar que Euclides manifesta pela primeira vez o seu modo de composição artística como poeta aos 15 anos de idade. Parte da sua poesia, por precoce e rechaçada que fosse por ele, voltará sempre a interessar ao autor, que continuou, ao longo da vida, reescrevendo alguns versos e compondo outros novos com a parcimônia e o empenho de quem lapida uma pedra preciosa. Sem dúvida, as faculdades criadoras de poeta ele as tinha: razão para controlar os impulsos da imaginação; imaginação para engenhosamente revelar o seu estro e, consequientemente, a sua singularidade de escritor; e, finalmente, sensibilidade para humanizar a sua obra e, assim, fazer com que a percebamos como muito próxima das nossas emoções. Difícil seria pensar em Euclides, já como historiador, sem essas três categorias; como seria impossível dar o título de grande historiador a qualquer outro escritor a quem faltassem tais faculdades.
22 Para um estudo do autor, das datas de publicação e do tex o, consultar "Antônio Maciel. O Conselheiro de Júlio Césa Leal", in Walnice Nogueira Gavão Mitológica Rosiand, São Paulo, Ática, 1978.

23 Consultar o nosso ensaio: "A Ontologia Discursiva de Os Sertões" in História Ciências Saúde - Manguinhos, vol. V 1988, pp. 57-72. Seguimos naquele e no presente traba tho as idéias de Hayden White em Tropics of Discourse Baltimore/Londres, The John Hopkins UP, 1978). 